\title{
Food Security and Nutritional scenario of India- an overview
}

\author{
Prasanna Kumar, H. $\mathbf{M}^{1}$., Harish Kumar, H. V ${ }^{2}$. \\ Agriculture Development and Rural Transmission Centre (ADRTC), \\ Institute for Social and Economic Change (ISEC), Bangalore, India - 560072
}

\begin{abstract}
The purpose of this paper is to assess the availability of food to poor and nutritional situation of national households. The growth of production of food grains is 2.12 per cent in 2000-01 to 2010-11, where as in 1980s, 2.85 per cent and overall growth in area of food grains has increased from 0.23 per cent in 1980s to 0.37 per cent in 2000-01 to 2010-11. But, subsequent declines can be observed in area and production of coarse cereals, pulses and total fibres. In addition, total investment on agriculture and allied Sectors has increased from Rs.90710 crore in 2006-07 to Rs. 133377 crore in 2009-10. In the contest of per capita net availability of food grains have been increased by around 10 per cent over the last 56 years. And India's hunger index declines from 24.1 to 23.7 registering a decline of just $1.7 \%$ in the period of 2001 to 2011 and all India average for malnourished children is 47\% in 2005-06. However, essential efforts to cope a food production with the population growth and remained self sufficient in food, establishment of adequate buffer stocks has ensured availability of food stuffs within affordable cost even during the times of drought and sustainable intensification of agricultural production.
\end{abstract}

Keywords: food security, malnutrition, Investments on agriculture, Buffer stocks, Procurement prices

\section{Introduction}

Food is essential to alive, no one can pretend when natural disaster will sweep out all crop area, which perhaps by flood, drought and other irregularities in weather leads to loss of production, therefore food is nessecery to feed the population during these conditions. Thus, securing of food is essential to nation and/or world. Therefore, the challenge is to supply sufficient and nutritious food against growing population, which is projected to reach $9 \mathrm{Bn}$ by 2050 . "Food security exists when all people, at all times, have physical, social and economic access to sufficient, safe and nutritious food which meets their dietary needs and food preferences for an active and healthy life" (FAO website). In the other hand, adequate nutrition is essential for economic growth, good health and physical and cognitive development. It requires a diverse diet including staple foods, vegetables, fruits, animal-source foods. While levels of nutrition are affected not only by food availability and access but also by sanitation - such as access to safe drinking water - and disease. In addition, education can also play a vital role in improving nutritional intake and balance (FAO statistical Year Book, 2012). In the world number of people without enough food to eat on a regular basis remains stubbornly high, at nearly over 800 million, and is not falling significantly by taking measures to minimise. Furthermore, Over $60 \%$ of the world's under nourished people live in Asia, and a quarter in Africa. The proportion of people who are hungry, however, is greater in Africa (33\%) than Asia (16\%). The latest FAO figures indicate that there are 22 countries, 16 of which are in Africa, in which the undernourishment prevalence rate is over 35\%.The world is facing a potential crisis of food security (World Hunger report, 2012).

\section{India's scenario}

The Indian economy is growing in historical way with an unprecedented rates and adding, second fastest-growing economies in the Asia after the china. The real GDP grew at 3.95\% a year per head from 1980 to 2005 , and at $5.4 \%$ a year from 2000 to 2005 (Deaton and Dreze, 2009). Besides, rice and wheat are the staple food products and government of India maintains buffer stock of these two commodities to face the irregularities emerged in future. Right now India has self sufficient food grains. In general, sustains in food security stands on three basic pillars: namely, (i) Sufficient quantities of food available on a consistent basis. (ii) Having sufficient resources to obtain appropriate foods for a nutritious diet. (iii) Appropriate use based on knowledge of basic nutrition and care, as well as adequate water and sanitation. Once the country fulfils all these targets, feed the population efficiently. Here, matter of concern that the cereal production has kept pace with the increasing requirements and average per capita intakes of cereal have remained satisfactory, there has been a fall in the per capita consumption of pulses. And New York Times cited analysts saying that 40 per cent of subsidized food never reaches its intended recipients because of India's inefficient distribution system (APFS Update, Jan 2012). It is important not only to improve production but also make them available at affordable cost. Furthermore, malnutrition is a gigantic problem, especially in children's and women's. According to the International Food Policy Research Institute's (IFPI) 2011 around 60 million children in India are underweight and malnourished and nearly 21 per cent of the population are malnourished. The introduction of the National 
Food Security Bill threatening to continue market inefficiencies in food supply and extend the problem of malnutrition far into the future (diplomat.com). In addition, the report of World Bank says productivity losses in India due to stunted growth, iodine deficiencies, and iron deficiencies are equivalent to almost 3 percent of GDP.

The objective of this paper is to (a) Evaluate the status of food availability in India. (b) Accessibility to food and nutrition requirements at the household at national level. (c) Measures and policies taken to realize food and nutrition security. The main goals of this paper are to evaluate the performance, challenges, and policies in food security by means of availability and access to food and nutrition.

\section{Food production and availability}

Food security is both physical and economic access to food that meets people's dietary needs as well as their food preference. Food security as "when all people at all times have access to sufficient, safe, nutritious food to maintain a healthy and active life" (World Food Summit 1996). Food security is a complex sustainable development issue, linked to health through malnutrition, but also to sustainable economic development, environment, and trade. There is a great deal of debate around food security with some arguing that there is enough food in the world to feed everyone adequately; the problem is distribution, Future food needs can - or cannot - be met by current levels of production and National food security is paramount (WHO website, 2012). Food production depends on a wide range of factors, including access to fertile land, availability of labour, appropriate seeds and tools and climatic conditions. Alternatively, factors affecting food purchases include household income and assets as well as food availability and price in local markets. In emergency situations, other factors may come into play including physical security and mobility, the integrity of markets and access to land.

Table 1: Compound Growth Rates of Area, Production and Yield of Principal Crops during 1980-1990, 1990-2000 and 2010-2011 (Base: T.E.1981-82=100)

\begin{tabular}{llllllllll}
\hline \hline \multirow{2}{*}{ Crop } & \multicolumn{3}{c}{ 1980-81 to 1989-90 } & \multicolumn{3}{c}{ 1990-91 to 1999-2000 } & \multicolumn{3}{c}{ 2000-01 to 2010-11* } \\
\cline { 2 - 11 } & \multicolumn{1}{c}{$\mathrm{A}$} & $\mathrm{P}$ & $\mathrm{Y}$ & $\mathrm{A}$ & $\mathrm{P}$ & $\mathrm{Y}$ & $\mathrm{A}$ & $\mathrm{P}$ & $\mathrm{Y}$ \\
\hline \hline Rice & 0.41 & 3.62 & 3.19 & 0.68 & 2.02 & 1.34 & -0.10 & 1.51 & 1.61 \\
Wheat & 0.46 & 3.57 & 3.10 & 1.72 & 3.57 & 1.83 & 1.28 & 2.16 & 0.87 \\
Maize & -0.20 & 1.89 & 2.09 & 0.94 & 3.28 & 2.32 & 2.81 & 5.65 & 2.77 \\
Coarse Cereals & -1.34 & 0.40 & 1.62 & -2.12 & -0.02 & 1.82 & -0.75 & 2.80 & 4.24 \\
Total Cereals & -0.26 & 3.03 & 2.90 & 0.04 & -0.02 & 1.59 & 0.09 & 2.01 & 3.19 \\
Total Pulses & -0.09 & 1.52 & 1.61 & -0.60 & 0.59 & 0.93 & 1.62 & 3.35 & 1.90 \\
Total Food & -0.23 & 2.85 & 2.74 & -0.07 & 2.02 & 1.52 & 0.37 & 2.12 & 2.89 \\
grains & & & & & & & & & \\
Total Oilseeds & 1.51 & 5.20 & 2.43 & -0.86 & 1.63 & 1.15 & 2.14 & 4.60 & 3.59 \\
Total Fibres & -1.50 & 2.46 & 3.98 & 2.45 & 2.21 & -0.27 & 2.15 & 11.76 & 9.55 \\
\hline \hline
\end{tabular}

Source: Directorate of Economics and Statistics, Department of Agriculture and Cooperation.

*Based on fourth advance estimates released on 19.07.2011.

Over all Food grains production in the country increased from about 50 million tonnes in 1950-51 to around 241 million tonnes in 2010-11 and production during 2009-10 is estimated at 218.11 million tonnes which is 16.36 million tonnes or $6.98 \%$ less than 234.47 million tonnes in 2008-09. Particularly, the kharif food grains production estimated at 103.95 million tonnes in 2009-10 is 14.19 million tonnes or $12 \%$ less than 118.14 million tonnes in 2008-09 and in rabi, production estimated at 114.16 million tonnes which is 2.17 million tonnes or $1.87 \%$ less than 116.33 million tonnes in 2008-09 (Annual report, 2011). Table 1 depicts the annual growth of food grains and observed the 2.12 per cent of growth in production and 0.37 per cent in area from 2000-01 to 2010-11. But in coarse cereals, pulses and total fibres have gradually declined in area and production. In fact, wheat and rice are critical for India's food security but their share of production has declined over last couple of years, while yields are stepping up. The growth rate of rice and wheat around 3.62 and 3.57 per cent per annum between 1980s and in 2010-11, it has declined to 1.51 and 2.16 per cent respectively. From the last two decades growth rates of production of total cereals has declined to 2.01 per cent from 3.03 per cent during the period 1980s as compared to the period 2010-11 (Table 1). The growth rate of production was much lower than that of population in the latter period. Similarly, growth rate of yields of food grains slightly increased from 2.74 per cent to 2.89per cent. 


\section{Status of area, input use and credit to agriculture in India}

Credit and modern agricultural technologies have occupied major share of agricultural development across Indian regions and credit has played vital role in agricultural growth and development. In addition to that, observed the gradual decelerate of the farmer's dependency on money lenders by multiplication of lending institutions along with the liberal procedure to get credit through various schemes and micro finance. Yet, noninstitutional credit agents still survive as they follow the canons of financing. The importance of farm credit as a critical input to agriculture in macro level for sufficient production and its role in poverty alleviation as well. Growth rate of Credit/loan issue moves towards agriculture is increased massively from 13.35 per cent in 1980 s to 24.28 per cent in last decade (2000-01 to 2010-11).

The supply side, performance of agriculture is affected by several factors, which interact among each other. These factors are from nature (including rainfall), technology, infrastructure (including irrigation), and the economic environment covers price forecasts and institutions. In recent, more than half of all public investments on agriculture have been spent on irrigation and the net irrigated area expanded from 20.85 million hectares in 1950-51 63.2 million hectares in 2008-09. Net sown area constituted $87 \%$ of operated land during the kharif season and $57 \%$ during the rabi season. About $64 \%$ of net sown area was under cereal cultivation in both the seasons of the agricultural year (GoI press report, 2002-03). The below table shows growth rate of net sown area is about 0.2 per cent per annum between 2000s, where as -0.12 per cent per annum in 1980s and total cropped area expanded to 195.10 million hectares in 2008-09 with a growth rate of 0.86 per cent per annum between 2000-01 to 2008-09 from 0.37 per cent in 1980s. Expansion has been observed only in the case of agricultural credit (Table 2). However, recent year's agricultural growth of more than 4 per cent was recorded between 2003-04 and 2007-08.

Table 2: Compound growth rate for area, input use and credit to agriculture (1980-81 to 2008-09)

\begin{tabular}{llll}
\hline \hline Parameters & 1980-81to 1989-90 & $\begin{array}{l}1990-91 \\
00\end{array}$ & to 1999- $\begin{array}{l}2000-01 \text { to 2008- } \\
09\end{array}$ \\
\hline \hline NPK Use (Lakh tonnes) & 7.77 & 4.41 & 5.43 \\
Net sown area (mha) & -0.12 & -0.05 & 0.20 \\
Total cropped area(mha) & 0.37 & 0.39 & 0.86 \\
Gross Irrigated Area (mha) & 2.24 & 2.61 & 2.27 \\
Cropping Intensity & 0.49 & 0.44 & 0.66 \\
Area under F\&V (000) & 3.20 & 2.23 & 2.78 \\
Credit Issued (Rs.Crores) & 13.35 & 17.65 & 24.28 \\
\hline \hline
\end{tabular}

Source: Dept. of Agriculture and Cooperation and Reserve Bank of India, Govt. of India

During Eleventh Plan Steering group has identified technological change, input use, public investment and diversification towards high value commodities like fruits and vegetables are the most important factors determinants of growth. The terms of trade turned against agriculture leads to reduced profitability of farming quite sharply and this occurred partly because of low domestic food demand and partly because removal of quota restrictions under World Trade Organization (WTO) made Indian farm prices to become more aligned with corresponding international prices at a time when these were in decline (GoI, 2009). Furthermore, farm distress was also most important factor made to decline the profitability to farmers. More generally, farmers are now subject to greater risk because variability of world prices is much higher than what Indian farmers have been used to in the past.

\section{Capital Investment on Agriculture}

Fig 1 depicted the total investment in the agriculture and allied Sectors has increased from Rs.90710 crore in 2006-07 to Rs.133377 crore in 2009-10. Similarly, public and private investment were increased from Rs. 22987 crore and Rs.67723 in 2006-07 to Rs. 23635 crore and Rs. 109742 crore in 2009-10 respectively. In 2011-12, agriculture and allied sectors grew 2.5\% and their share in the GDP fell from 14.7\% in 2009-10 to $13.9 \%$ in $2011-12$. 


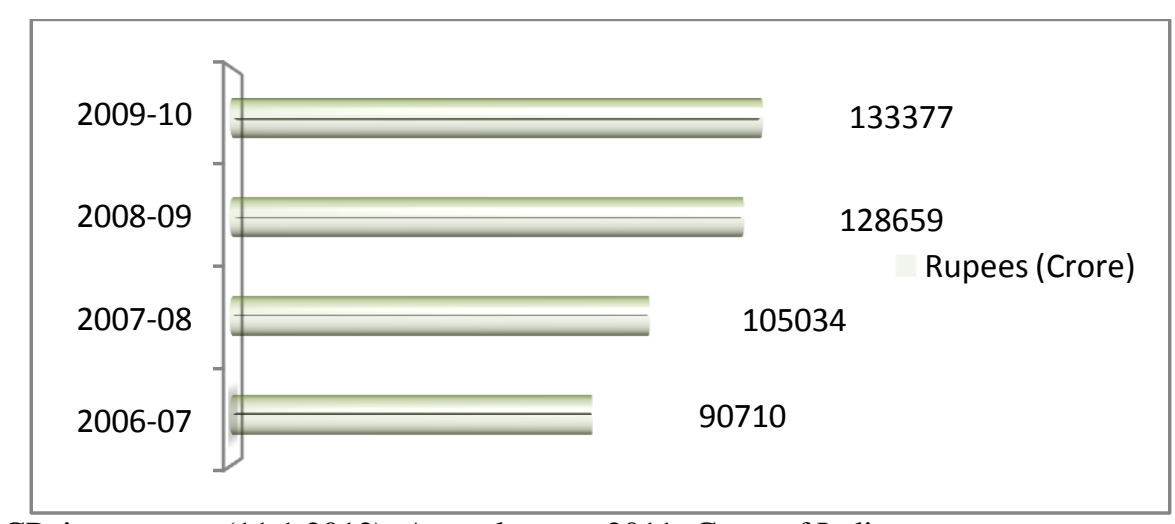

Source: MP: CP: investment (11.1.2012), Annual report 2011, Govt. of India

[Note: all in Rs crore, at 2004-05 prices]

Fig1: Gross capital investment in agriculture and allied sectors during 2006-2011

Agriculture's share in the economy's overall gross capital formation also declined from 8.3\% in 2008-9 to $7.2 \%$ in 2010-11 and farmers are unable to meet demand because they remain hampered by low capital investment, obsolete technology, and shortage of basic inputs such as water, fertilisers, seed, and energy (Economic Survey 2012). Private investment in agriculture stagnated as a result, the area cultivated fell. As per the latest estimates, the public and private investment (Gross Capital Formation- GCF) in Agriculture and Allied Sectors (Agriculture including livestock, forestry \& logging and fishing) has been growing steadily during the recent years.

Per Capita Availability of Food grains

Table 3: Per capita net availability per day of various food products in India (From 1970 to 2010)

\begin{tabular}{|c|c|c|c|c|c|c|c|}
\hline Years & $\begin{array}{l}\text { Cereals } \\
\text { (grams) }\end{array}$ & $\begin{array}{l}\text { Pulses } \\
\text { (grams) }\end{array}$ & $\begin{array}{l}\text { Total } \\
\text { (grams) }\end{array}$ & $\begin{array}{l}\text { Edible } \\
\text { (Kg.) }\end{array}$ & Oil & $\begin{array}{l}\text { Vanaspathi } \\
\text { (Kg.) }\end{array}$ & Sugar (Kg.) \\
\hline 1970 & 403.1 & 51.9 & 455 & 3.5 & & 1 & 7.4 \\
\hline 1980 & 379.5 & 30.9 & 410.4 & 3.8 & & 1.2 & 7.3 \\
\hline 1990 & 435.3 & 41.1 & 476.4 & 5.5 & & 1 & 12.7 \\
\hline 2000 & 422.7 & 31.8 & 454.4 & 8.2 & & 1.3 & 15.8 \\
\hline 2001 & 386.2 & 30 & 416.2 & 8.8 & & 1.4 & 16 \\
\hline 2002 & 458.7 & 35.4 & 494.1 & 7.2 & & 1.4 & 16.3 \\
\hline 2003 & 408.5 & 29.1 & 437.6 & 9.9 & & 1.2 & 16.1 \\
\hline 2004 & 426.9 & 35.8 & 462.7 & 10.2 & & 1.1 & 15.5 \\
\hline 2005 & 390.9 & 31.5 & 422.4 & 10.6 & & 1.1 & 16.3 \\
\hline 2006 & 412.8 & 32.5 & 445.3 & 11.1 & & 1.2 & 16.8 \\
\hline 2007 & 407.4 & 35.5 & 442.8 & 11.4 & & 1.2 & 17.8 \\
\hline 2008 & 394.2 & 41.8 & 436 & 12.7 & & 1.3 & 18.8 \\
\hline 2009 & 407 & 37 & 444 & 13.3 & & 1.1 & 17.9 \\
\hline 2010P & 407 & 31.6 & 438.6 & 13.6 & & 1 & 17 \\
\hline
\end{tabular}

Source: Economic Survey 2011-12, Govt. of India

The per capita net availability of foodgrains increased by around 10 per cent over the last 56 years, but compare to previous year and also to 1970 (455 grams per day) with 2010 (438.6 grams), by overall net availability is declined (Table 3). In addition, significant increase in production of foodgrains has not been able to keep pace with the increase in population. In the year 2010, per capita availability of food grains was only 438.6 grams. During the period 1970 to 2010, per capita availability of pulses has declined significantly. On the other hand, per capita availability of sugar and edible oils has increased over time. 
Food Security and Nutritional scenario of India- an overview

Table 4: Per capita Availability and Deficit of other than food grains

\begin{tabular}{|l|l|l|l|}
\hline Food Items & \multicolumn{1}{|c|}{$\begin{array}{c}\text { Per capita } \\
\text { availability }\end{array}$} & $\begin{array}{c}\text { ICMR recommendations } \\
\text { for Indians }\end{array}$ & Per capita deficit \\
\hline Milk & 246 grams/day & 250 grams/day & 06 grams/day \\
\hline Egg & 42 eggs/annum & 180 eggs/annum & 138 eggs/annum \\
\hline Vegetables & 179 grams per day & 300 grams per day & 121 grams per day \\
\hline Fruits & 58 grams per day & 92 grams per day & 34 grams per day \\
\hline
\end{tabular}

The per capita availability of fruits was 58 grams per day and 179 grams per day for vegetables. Table 4 provides per capita availability and deficit of milk, egg and meat. It shows the need for increase in availability of non-cereal food. In terms of non-cereal food like fruits, vegetables, milk, meat and fish, all this figures depicts that India has not achieved self sufficiency in terms of per capita availability.

\section{Demand and Supply Projections}

Till now many studies have been done on demand and supply projections. For example, Hanchate and Dyson (2004) projected demand and supply for total cereals for 2026 at 217.6 million tonnes and 265.8 million tonnes respectively and Mittal (2006) projected demand for rice at 84.2 million tonnes for 2011, 96.4 million tonnes for 2021, and 101.5 million tonnes for 2026 . The corresponding supply projections are $95.7,105.8$, and 111.2 million tonnes respectively, envisaging a surplus of $11.46,9.38$, and 9.73 million tonnes respectively and projections for wheat demand are 59.8, 66.1, and 68.1 million tonnes for the above mentioned years as compared to the supply projections of 80.2, 91.6, and 97.9 million tonnes indicating surpluses of 20.41, 25.53, and 29.84 million tonnes for 2011, 2021, and 2026 respectively. For total cereals, the projected surpluses are 27.59, 12.76, and 4.63 million tonnes (Mahendra et. al, 2010). Table 5 shows projected demand and estimated food grain production, it depicts that India would be self sufficient in food grains in future. According to projections, for 2010-11 India have surplus in the Food grains except rice, pulses and oilseeds too. Apart, projected demand rice have deficit of -8.91MT in 2010-11 and for 2025, demand for food grains increased gradually but fails to equalize with cope of population growth (Table 5 ). In addition, the demand for milk and milk products would increase from 64 million tonnes in 2000 to 166 million tonnes in 2020, and fruits and vegetables from 48 million tonnes to 113 million tonnes (Radhakrishna, 2002) and Ministry of Agriculture projected demand for food grains of around 250 million tonnes for 2020 are reasonable.

Table 5: Estimated production and projected demands for food grains

\begin{tabular}{|c|c|c|c|c|c|c|c|c|}
\hline Crops & $\begin{array}{l}2009-10 \\
\text { Projected } \\
\text { Demand }\end{array}$ & $\begin{array}{l}\text { Estimated } \\
\text { production }\end{array}$ & $\begin{array}{l}\text { Surplus/ } \\
\text { Deficit }\end{array}$ & $\begin{array}{l}2010-11 \\
\text { Projected } \\
\text { Demand }\end{array}$ & $\begin{array}{l}\text { Estimated } \\
\text { production }\end{array}$ & $\begin{array}{l}\text { Surplus/ } \\
\text { Deficit }\end{array}$ & $\begin{array}{l}2020 \\
\text { Projected } \\
\text { Demand }\end{array}$ & $\begin{array}{l}2025 \\
\text { Projected } \\
\text { Demand }\end{array}$ \\
\hline $\begin{array}{l}\text { Rice } \\
\text { Wheat }\end{array}$ & $\begin{array}{l}94.70 \\
80.69\end{array}$ & $\begin{array}{l}89.09 \\
80.80\end{array}$ & $\begin{array}{l}-5.61 \\
0.11\end{array}$ & $\begin{array}{l}96.01 \\
82.11\end{array}$ & $\begin{array}{l}87.10 \\
85.93\end{array}$ & $\begin{array}{l}-8.91 \\
3.82\end{array}$ & $\begin{array}{l}109.11 \\
96.31\end{array}$ & $\begin{array}{l}115.66 \\
103.41\end{array}$ \\
\hline $\begin{array}{l}\text { Coarse } \\
\text { cereals }\end{array}$ & 36.03 & 33.55 & -2.48 & 36.30 & 42.22 & 5.92 & 39.00 & 40.35 \\
\hline Food Grains & 224.87 & 218.11 & -6.76 & 227.93 & 241.57 & 13.64 & 258.53 & 273.83 \\
\hline Pulses & 14.51 & 14.66 & 0.15 & 14.59 & 18.09 & 3.50 & 15.39 & 15.79 \\
\hline Oilseeds & 25.36 & 24.88 & -0.48 & 25.76 & 31.10 & 5.34 & 29.76 & 31.76 \\
\hline Sugar cane & 316.02 & 292.30 & -23.72 & 320.76 & 339.17 & 18.41 & 368.16 & 391.86 \\
\hline
\end{tabular}

Source: Compiled by author (considered from 1950-51)

\section{Management of Food grains}

Food grains demand and production of the country has grown at less than population. Typically, concluded that India has moved from deficits to permanent surplus and excess stocks are more accurately attributed to a fall in consumption than to increased production. But India's system of grain management is in crisis. Huge public stocks have been built up, foregoing consumption in the past few years. These stocks are deteriorating because of shortage of storage space, lack of rural infrastructure development and so on. In general, food grain management involves three functions - production, procurement and distribution. Already discussed about the production aspect and is more criticise because of low production, lack of productivity etc and/or distribution aspects like lack of access to food in rural areas as well urban areas and really food stocks rotting but people dying of hunger etc. 


\section{Minimum Support Prices and Procurement}

Price Policy for agricultural commodities seeks to ensure remunerative prices to growers for their produce with a view to encouraging higher investment and production, and at the same time, safeguarding the interest of consumers by making available supplies at reasonable prices. A lot of publicity is still needed with regard to minimum support prices (MSP) as only 19 per cent of the farmers knew about MSP, while another 10 per cent knew about it but did not know where to sell their produce (Saxena, 2009) and provides minimum support prices (MSP) for major agricultural products announced each year are fixed taking into account the recommendations of the Commission for Agricultural Costs and Prices (CACP). Presently, the CACP recommends MSPs for 24 important crops. There has been significant increase in MSP for crops during the period 2006-07 to 2012-13. For 'A' grade variety of paddy, the support price has been raised to Rs. 1280 per quintal from Rs. 1110, accounts 15.32 per cent hike and for common variety, has been increased from Rs 1080 per quintal to Rs 1250 per quintal in 2012-13, while maximum increase has been in the case of jowar with over 53 per cent, followed by ragi. Similarly, for wheat has increased only 5.33 per cent from Rs. 1220 to Rs. 1285 but from 2006-07 to 2011-12, for wheat increased by 71.33 per cent. At the same time, MSP for urad, groundnut, soyabean and sunflower has been increased by over 30 per cent.

Table 6: Minimum Support Prices for principle Crops in India (2006-2007 to 2011-2012)

\begin{tabular}{|c|c|c|c|c|c|c|c|}
\hline \multirow[b]{2}{*}{ Commodity } & \multirow[b]{2}{*}{ Variety } & \multirow{2}{*}{$\begin{array}{l}2001- \\
02\end{array}$} & \multirow{2}{*}{$\begin{array}{l}2006- \\
07\end{array}$} & \multirow{2}{*}{$\begin{array}{l}2011- \\
12\end{array}$} & \multicolumn{3}{|c|}{$2012-13$} \\
\hline & & & & & MSP & $\begin{array}{l}\text { Value } \\
\text { change }\end{array}$ & $\begin{array}{l}\% \\
\text { Change }\end{array}$ \\
\hline \multirow[t]{2}{*}{ Paddy } & Common & 530 & 580 & 1080 & 1250 & 170 & 15.74 \\
\hline & Grade 'A' & 560 & 610 & 1110 & 1280 & 170 & 15.32 \\
\hline Wheat & & 620 & 650 & 1220 & 1285 & 65 & 5.33 \\
\hline Maize & & 485 & 540 & 980 & 1175 & 195 & 19.90 \\
\hline \multirow[t]{2}{*}{ Jowar } & Hybrid & 0 & 540 & 980 & 1500 & 520 & 53.06 \\
\hline & Maldandi & 0 & 555 & 1000 & 1520 & 520 & 52.00 \\
\hline Bajra & & 0 & 540 & 980 & 1175 & 195 & 19.90 \\
\hline Barley & & 500 & 550 & 780 & 980 & 200 & 25.64 \\
\hline Tur (Arhar) & & 1320 & 1410 & 3200 & 4000 & 800 & 25.00 \\
\hline Urad & & 1330 & 1520 & 3300 & 4300 & 1000 & 30.30 \\
\hline $\begin{array}{l}\text { Groundnut-in- } \\
\text { Shell }\end{array}$ & & 1355 & 1520 & 2700 & 3700 & 1000 & 37.04 \\
\hline Sunflower Seed & & 1195 & 1500 & 2800 & 3700 & 900 & 32.14 \\
\hline Safflower & & 1300 & 1565 & 2500 & 4200 & 1700 & 68.00 \\
\hline
\end{tabular}

Source: Indiaagristat.com, CACP

* An additional incentive bonus of Rs. 50 per quintal

** An additional incentive bonus of Rs. 100 per quintal

\section{Buffer stock of food grains}

The importance of buffer-stock is to build up stock at the time of harvest season to secure food to the country and provide at the time of famine, drought, variation in food grain output, due to man-made factors, variations in the weather conditions and other failures faced in future. Generally, wheat and rice are the major produce to maintain stock over the periods. it becomes essential for the country to ensure food security for feed the population by building adequate buffer stocks from the surpluses in good production years and even during scarcity in production if food grains, it has to be maintained by importing.

Table 7: Procurement of Rice and Wheat

(Figures in lakh tonnes)

\begin{tabular}{llllll}
\hline \hline Years & $2006-07$ & $2007-08$ & $2008-09$ & $2009-10^{*}$ & $2010-11^{* *}$ \\
\hline \hline Rice & 251.07 & 287.36 & 341.04 & 314.57 & 142.29 \\
Wheat & 92.26 & 111.28 & 226.89 & 253.82 & 225.14 \\
\hline \hline
\end{tabular}

Source: Department of Food and Public Distribution System, GoI

* Position as on $01 / 10 / 2010$, ** Position as on 31.12.2010 
During kharif marketing Season 2009-10 (October 2009 to September 2010), there was a record procurement of 314.57 lakh tonnes of rice against previous record of 341.04 lakh tonnes in same season 2008-09 (Table 7). Procured for the central pool during the rabi

Table 8: Stock position of Wheat \& Rice in the Central Pool vis-à-vis minimum buffer norms:

\begin{tabular}{|c|c|c|c|c|c|c|}
\hline Years & Wheat & & Rice & & Total & \\
\hline $\begin{array}{lll}\text { (As on 1st } \\
\text { July) }\end{array}$ & $\begin{array}{l}\text { Actual } \\
\text { Stock }\end{array}$ & $\begin{array}{l}\text { Minimum } \\
\text { Buffer norms }\end{array}$ & $\begin{array}{l}\text { Actual } \\
\text { Stock }\end{array}$ & $\begin{array}{l}\text { Minimum } \\
\text { Buffer norms }\end{array}$ & $\begin{array}{l}\text { Actual } \\
\text { Stock }\end{array}$ & $\begin{array}{l}\text { Minimum } \\
\text { Buffer norms }\end{array}$ \\
\hline 2003 & 241.94 & 143 & 109.74 & 100 & 351.68 & 243 \\
\hline 2004 & 191.52 & 143 & 107.63 & 100 & 299.15 & 243 \\
\hline 2005 & 144.54 & 171 & 100.71 & 98 & 245.25 & 269 \\
\hline 2006 & 82.07 & 171 & 111.43 & 98 & 193.5 & 269 \\
\hline 2007 & 129.26 & 171 & 109.77 & 98 & 239.03 & 269 \\
\hline 2008\# & 249.12 & 201 & 112.49 & 98 & 361.61 & 299 \\
\hline 2009 & 329.22 & 201 & 196.16 & 118 & 525.38 & 319 \\
\hline 2010 & 335.84 & 201 & 242.66 & 118 & 578.5 & 319 \\
\hline $2011 *$ & 215.4 & 112 & 255.8 & 138 & 471.2 & 250 \\
\hline
\end{tabular}

Source: Ministry of Consumer Affairs, Food and Public Distribution, 2010-11.

\# Includes Food Security Reserve of 30 lakh tonnes of wheat from 1.7.2008 onwards and 20 lakh tonnes of rice from 1.1.2009 onwards.

* Up to 01.01.2011.

marketing season 2009-10 (April 2009 to March 2010) against 226.89 lakh tonnes during Rabi 2008-09. In rabi marketing season 2010-11, 225.14 lakh tonnes of wheat has been procured. Till 31st December, 2010, 142.29 lakh tonnes of rice has been procured in kharif marketing season 2010-11(Annual report 2011, GoI). And 253.82 lakh tonnes of wheat has been procured and various committees have suggested the optimal size of the buffer-stock depending on the season and requirements. Table 8 shows the actual level and the norm for buffer stocks as on 1st July for the years between 2003 and 2011. The procurement prices is always higher than market prices, the obligation to purchase all grains offered by the farmers led to accumulation of rice and wheat stocks to the extent of 63 million tonnes by July 2002. These stocks of 63 million tonnes were much above the optimal stocks of 15 to 25 million tonnes recommended by various committees before 2009, but in 2009 which has increased to 30 million tonnes of Wheat and 20 million tonnes of rice as a food security reserve. In 2010, actual stock was 578.5 MT with buffer norms of $319 \mathrm{MT}$. And it has declined to 471.2MT of actual stock and buffer norms of $250 \mathrm{MT}$ which is included of food security reserve.

\section{Accessibility to Food and Nutrition}

\section{Hunger}

The meaning of huger is uneasy and/or painful to get want of food. A recent FAO estimated facts 925 million hungry people and around 13.1 per cent of total world population and almost 1 in 7 people are hungry. In fact, the hunger due to three factors, firstly because of neglect of agriculture relevant to very poor people by governments and international agencies. Secondly, the current worldwide economic crisis, and finally, the significant increase of food prices in the last several years (World Hunger and Poverty Facts and Statistics, 2012).

India's hunger index was at 30.4 in 1990 and ranked 62 in the list of 74 countries. Even though India has enough food (food stock of 50 million tonnes projected in 2009) and its GDP has more than doubled since 1991, it is home to about 25 percent of the world's hungry poor. 48 percent of children under the age of five years are malnourished in India, which is over a third of the world's 150 million malnourished under-fives. Also over half of all women aged between 15 and 49 years are anaemic, and 30\% of children are born underweight. It is estimated that $3 \%$ of GDP is lost by physical impairments caused by malnutrition in Asian countries (Economist 2010a). India ranked a high of 65 in 2009 with a global hunger index of 23.9, which is higher than many countries in sub-Saharan Africa including Sudan (Table 9). 
Table 9: Global Hunger Index (GHI) for some Countries, 1981 - 2009

\begin{tabular}{|c|c|c|c|c|c|c|}
\hline $\begin{array}{l}\text { GHI } \\
\operatorname{Rank}(2009)\end{array}$ & Country & 1981 & 1992 & 1997 & 2003 & 2009 \\
\hline N/A & Brazil & 10.43 & 8.5 & 6.7 & 5.43 & $<5$ \\
\hline N/A & Russian federation & $\ldots \ldots \ldots$ & $\ldots \ldots \ldots$ & 3.8 & 2.93 & $<5$ \\
\hline 5 & China & 20.1 & 12.57 & 8.57 & 8.23 & 5.7 \\
\hline 65 & India & 41.23 & 32.8 & 25.73 & 25.73 & 23.9 \\
\hline 35 & Sri Lanka & 24.9 & 22.4 & 21.87 & 16.63 & 13.7 \\
\hline 55 & Nepal & 43.3 & 27.77 & 27.77 & 24.5 & 19.8 \\
\hline 58 & Pakistan & 33.6 & 25.97 & 23.6 & 21.77 & 21 \\
\hline 67 & Bangladesh & 44.4 & 36.5 & 35.73 & 28.27 & 24.7 \\
\hline N/A & Egypt & 13.63 & 6.63 & 7 & 5.17 & $<5$ \\
\hline 14 & South Africa & $\ldots \ldots \ldots$ & 7.46 & 7.32 & 7.66 & 7 \\
\hline 38 & Uganda & 24.63 & 21.83 & 21.73 & 18.63 & 14.8 \\
\hline
\end{tabular}

Source: (Ruth Kattumuri 2011).

Recently, in 2011 the index is at 23.7 and India is placed at 67 in a list of 81 countries. In the period 1990-2011, there are 47 countries that have lowered hunger more than India with Peru topping the list. India's hunger index declines from 24.1 to 23.7 registering a decline of just $1.7 \%$ in the period of 2001 to 2011 . There are 73 countries which have performed better in reducing the hunger levels (GoI, 2011) ${ }^{1}$.

\section{Food insecurity and nutritional Intake}

The components of food insecurity are: a) Shortage of food or household food depletion, b) lack of quality food or suitable food for the household and/or a presence of nutritionally inadequate monotonous diet, c) Preoccupation and/or worry about the present and future uncertainty of the household food supply and, d) a lack of control over the household's food situation. In the other hand, the per capita calorie intake for rural population declined to $2047 \mathrm{kcal}$ per day in 2005-06 from $2240 \mathrm{kcal}$ per day in 1983 and it has increased in $66^{\text {th }}$ round (2009-10) to $2147 \mathrm{kcal}$, but compare to 1983, per capita calorie intake has been decreased and per capita protein consumption of rural areas has slightly increased from 63.5 grams in 1983 to 59.3 grams per day in 2009-10.

Table 10: Poverty ratio of selected State-Wise by Social Groups (2004-05)

\begin{tabular}{llllllllll}
\hline \hline \multirow{2}{*}{ State } & \multicolumn{1}{c}{ Rural } & \multicolumn{9}{c}{ Urban } & \multicolumn{2}{c}{ Rural \& Urban } \\
\cline { 2 - 9 } & SC & OBC & Others & All & SC & OBC & Others & All & Combined \\
\hline \hline Bihar & 64 & 37.8 & 26.6 & 42.1 & 67.2 & 41.4 & 18.3 & 34.6 & 41.4 \\
Chhattisgarh & 32.7 & 33.9 & 29.2 & 40.8 & 52 & 52.7 & 21.4 & 41.2 & 40.9 \\
Jharkhand & 57.9 & 40.2 & 37.1 & 46.3 & 47.2 & 19.1 & 9.2 & 20.2 & 40.3 \\
MP & 42.8 & 29.6 & 13.4 & 36.9 & 67.3 & 55.5 & 20.8 & 42.1 & 38.3 \\
Maharashtra & 44.8 & 23.9 & 18.9 & 29.6 & 43.2 & 35.6 & 26.8 & 32.2 & 30.7 \\
Orissa & 50.2 & 36.9 & 23.4 & 46.8 & 72.6 & 50.2 & 28.9 & 44.3 & 46.4 \\
UP & 44.8 & 32.9 & 19.7 & 33.4 & 44.9 & 36.6 & 19.2 & 30.6 & 32.8 \\
Uttarakhand & 54.2 & 44.8 & 33.5 & 40.8 & 65.7 & 46.5 & 25.5 & 36.5 & 39.6 \\
\hline \hline * All India & 36.8 & 26.7 & 16.1 & 28.3 & 39.9 & 31.4 & 16 & 25.7 & 27.5 \\
\hline \hline
\end{tabular}

Source: Ministry of Social justice and empowerment

Poverty: All India (Per capita per month) Rural Rs. 356.30 All India (Pre Capital per month) Urban Rs. 538.60. Legend: $\mathrm{SC}=$ Scheduled Castes; OBC $=$ Other Backward Castes.

In the same period, the rate of change in protein consumption is more in rural areas when compare to urban. Overall observations depict, for urban area has quite improvement is registered compare to rural and per capita consumption has increased, compare with 1983 (Table 10). Per capita calorie intake by quartiles in Table 11 shows that there was significant decline in the case of the top quartile while for the bottom quartile it has been stagnant and per capita calorie consumption for the bottom decile was very low at 1485 kcal per day in 2004-05. This level is much below the norm of 2400 calories in rural areas. However, there is

\footnotetext{
${ }^{1}$ The hunger index is based on three indicators - undernourishment, child underweight and child mortality. Barring child mortality, India fares poorly in all the three sub-indicators (National Food Security Bill).
} 
Table 11: Total and cereal calorie consumption by decile and quartile of per capita expenditure, rural India, 1983 to 2004-05.

\begin{tabular}{llllll}
\hline \hline Years & $\begin{array}{l}\text { Bottom } \\
\text { decile }\end{array}$ & $\begin{array}{l}\text { Bottom } \\
\text { Quartile }\end{array}$ & $\begin{array}{l}\text { Second } \\
\text { Quartile }\end{array}$ & Third Quartile & Top Quartile \\
\hline \hline Total calories & & & & & \\
1983 & 1,359 & 1,580 & 2,007 & 2,328 & 3,044 \\
$1987-88$ & 1,488 & 1,683 & 2,056 & 2,334 & 2,863 \\
$1993-94$ & 1,490 & 1,659 & 2,000 & 2,251 & 2,702 \\
$1999-00$ & 1,496 & 1,658 & 1,978 & 2,250 & 2,707 \\
$2004-05$ & 1,485 & 1,624 & 1,900 & 2,143 & 2,521 \\
Cereal Calories & & & & & \\
1983 & 1,150 & 1,309 & 1,589 & 1,738 & 1,974 \\
$1987-88$ & 1,221 & 1,359 & 1,598 & 1,715 & 1,894 \\
$1993-94$ & 1,203 & 1,316 & 1,504 & 1,591 & 1,690 \\
$1999-00$ & 1,197 & 1,289 & 1,591 & 1,509 & 1,566 \\
$2004-05$ & 1,189 & 1,259 & 1,690 & 1,430 & 1,471 \\
\hline \hline
\end{tabular}

Source: Deaton and Dreze (2009)

a controversy over the minimum calorie consumption per consumer unit per diem. The present level of per capita calorie consumption for the bottom quartile is extremely low.

Table 12: Average per capita consumption of calories, protein, and fats

\begin{tabular}{llllllll}
\hline \hline & \multicolumn{2}{l}{ Calories $(\mathrm{kcal})$} & \multicolumn{3}{c}{ Protein (grms) } & \multicolumn{2}{l}{ Fats (grms) } \\
\cline { 2 - 8 } Year & Round & Rural & Urban & Rural & Urban & Rural & Urban \\
\hline \hline $1983-84$ & 38 & 2,240 & 2,070 & 63.5 & 58.1 & 27.1 & 37.1 \\
$1987-88$ & 43 & 2,233 & 2,095 & 63.2 & 58.6 & 28.3 & 39.3 \\
$1993-94$ & 50 & 2,153 & 2,073 & 60.3 & 57.7 & 31.1 & 41.9 \\
$1999-00$ & 55 & 2,148 & 2,155 & 59.1 & 58.4 & 36 & 49.6 \\
$2000-01$ & 56 & 2,083 & 2,027 & 56.8 & 55.3 & 34.6 & 46.1 \\
$2001-02$ & 57 & 2,018 & 1,982 & 54.8 & 54.2 & 33.6 & 46.1 \\
$2002-03$ & 58 & 2,025 & 2,014 & 55.4 & 54.9 & 34.7 & 47 \\
$2003-04$ & 59 & 2,106 & 2,020 & 58 & 55.5 & 36.4 & 46.7 \\
$2004-05$ & 60 & 2,087 & 2,036 & 56.9 & 55.9 & 35.5 & 46.8 \\
$2005-06$ & 61 & 2,047 & 2,021 & 55.8 & 55.4 & 35.4 & 47.4 \\
$2009-10$ & 66 & 2147 & 2123 & 59.3 & 58.8 & 43.1 & 53 \\
\hline \hline
\end{tabular}

Deaton and Dreze (2009), NSSO $66^{\text {th }}$ round data

\section{Micro nutrients and Malnutrition}

Micronutrients are differing from macronutrients such as carbohydrates, protein and fat, because they are essential and required in very small amounts to the body. Micronutrients are commonly called as vitamins and minerals. WHO estimated 250000 to 500000 vitamin A-deficient children become blind every year, half of them dying within 12 months of losing their sight. For pregnant women in high-risk areas, vitamin A deficiency occurs especially during the last trimester when demand by both the unborn child and the mother is highest. Crucial for maternal and child survival, supplying adequate vitamin A in high-risk areas can significantly reduce mortality. Conversely, its absence causes a needlessly high risk of disease and death (WHO, 2011). 


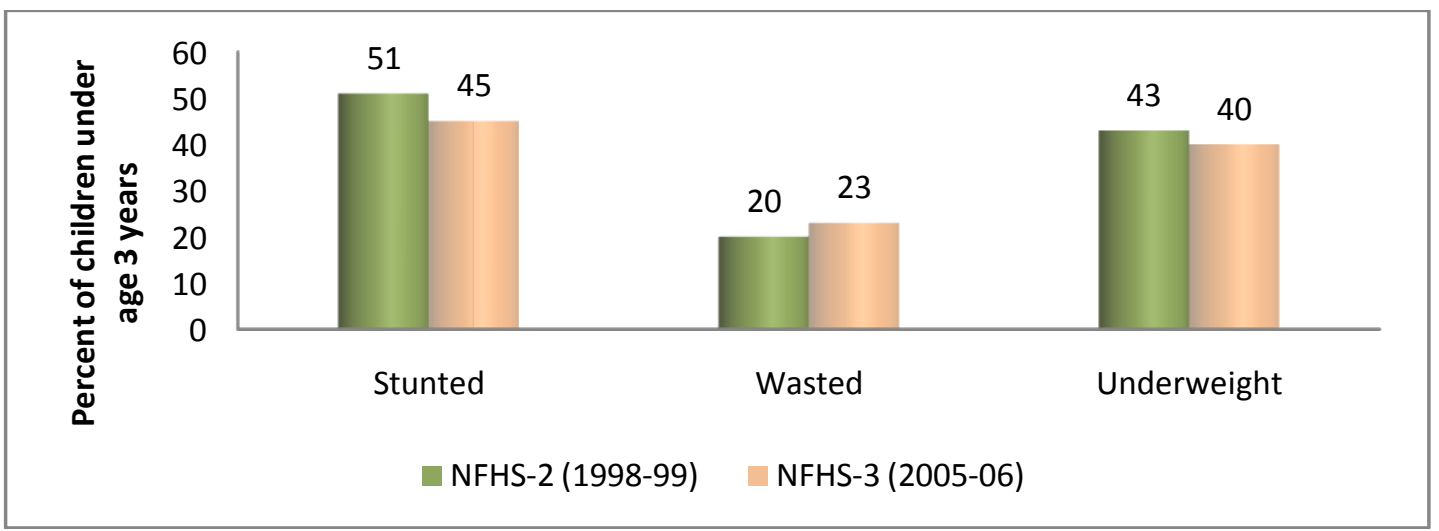

Source: India Country report 2010

\section{Figure 2: Trend in Nutritional Status of Children}

In India, children and adults are vulnerable to malnutrition because of low dietary intakes, infectious diseases, lack of appropriate care and inequitable distribution of food within the household. Figures depicts the proportion of stunting among children declined to a much greater extent from 51 per cent during 1998-99 to 45 per cent in 2005-06 and severe stunting also decreased from 28 percent to 22 percent. Other hand underweight children declined slightly to 45.9 per cent in 2005-06 from 47 per cent in 1998-99 and Wasting is also quite a serious problem in India, affecting 20 percent of children under five years of age Fig 2.

Fig 3 shows that the significant differences in malnutrition at the rural and urban levels. The proportion of underweight children was 49 per cent in rural is higher as compared to urban $(36 \%)$ and the proportion of stunted children was 31 per cent in urban area is lower than in rural areas of 41 per cent. In the other hand, wasted is around 17 and 21 per cent in urban and rural areas respectively.

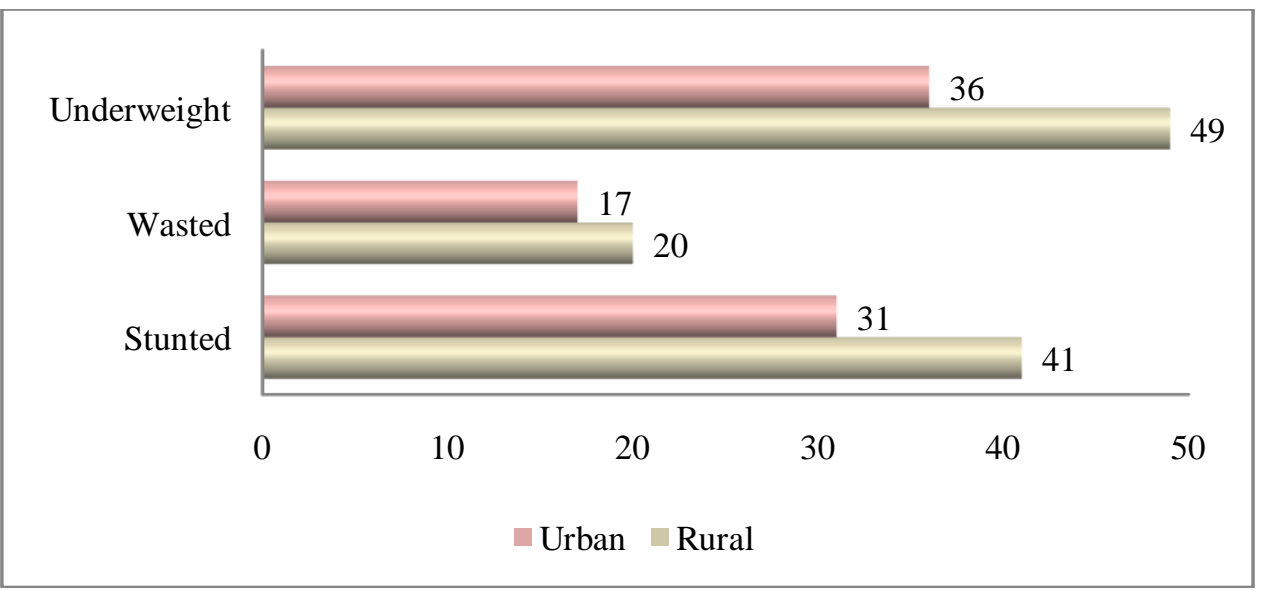

Source: National Family Heath Survey (NFHS), GoI

Fig 3: Malnutrition: NFHS-3 (2005-06) Rural and Urban

In India, anaemia is primarily linked to poor nutrition. Women and men suffer both from over nutrition and under nutrition. Even it is also common disorder among adults. Nearly half of women in India (55\%) are anaemic, especially among pregnant women. Anaemia levels in men are at around $24 \%$. More than one-third of women are too thin, while $13 \%$ are overweight or obese. According to the latest data collated by the National Health Survey 2005-06 the all India average for malnourished children is 47\%. Every second child under 5 years is malnourished. Even the prosperous states like Gujarat and Kerala there is rise in the number of malnourished children.

Comparison with NHFS-2 carried out five years ago shows that the proportion of wasted children has increased while underweight children are only marginally less. Similarly the proportion of anaemic infants has marginally increased. The number of pregnant women who are anaemic has jumped from about $49 \%$ to over $54 \%$ in these five years in these 19 states. The prevalence of anaemia among infants has declined in several states but it has not improves or even worsened in AP, Assam, Karnataka, Kerala, Meghalaya, Orissa, Punjab and UP. In no state has the proportion fallen below 50\%.Up, Rajasthan, Punjab, Haryana, Karnataka, Gujarat and Assam all have shockingly high proportions of anaemic infants-80\% or above. 
Table 13: Selected state-wise suffer of infants and pregnant women due to anaemia

\begin{tabular}{lllll}
\hline \hline & \multicolumn{2}{l}{} & \multicolumn{2}{c}{ (In Per } \\
\cline { 2 - 5 } States & Anaemic infants & & Anaemic pregnant women \\
\cline { 2 - 5 } & NFHS-3 & NFHS-2 & NFHS-3 & NHFS-2 \\
\hline \hline Assam & 76.7 & 63.2 & 72 & 62.3 \\
Karnataka & 82.7 & 70.6 & 59.5 & 48.6 \\
Kerala & 55.7 & 43.9 & 33.1 & 20.3 \\
Arunchal & 66.3 & 54.5 & 49.2 & 49.2 \\
Uttar Pradesh & 85.1 & 73.8 & 51.6 & 45.8 \\
AP & 79 & 72.3 & 56.4 & 41.8 \\
Gujarat & 80.1 & 74.5 & 60.8 & 47.4 \\
Orissa & 74.2 & 72.3 & 68.1 & 60.5 \\
Meghalaya & 68.7 & 67.6 & 56.1 & 58.6 \\
Punjab & 80.2 & 80 & 41.6 & 37.1 \\
\hline \hline
\end{tabular}

Source: National Family Heath Survey (NFHS), GoI

\section{Factors Determining Malnutrition}

Poverty and lack of purchasing power have been identified as two major factors responsible for low dietary intake. Poverty is usually mentioned as the main cause of malnutrition and others, such as lack of education and information about good or adequate nutrition, failure to consume vitamin supplements or fortified foods, and the cost of food. In general, protein intake is far below the World Health Organization's cut-off limits and shows that it continues to be a public health problem in India. In educational aspects, children's and women's are fail to access an adequate nutritional food and recommendations of various councils (ICMR, WHO).Furthermore, lack of a reasonable and low cost insurance to insures the risks of uncertainty of the farmer and his family due to of natural disasters against homes as well as on crop, medical facilities and maternity benefits. Apart, low subsidised facilities for purchasing agricultural equipments. And most important factor is that lack of access to credit and lack of government initiatives toward food security and nutrition.

Women face so many obstacles in attaining the adequate food and nutrition security. As we know, Indian rural women are small and marginal farming families perform over $60 \%$ of on-farm activities and almost all off-farm activities. However, their contribution does not receive recognition due to old-fashioned stereotypes embedded in the culture. Nevertheless, $21^{\text {st }}$ century, major areas of India discrimination several aspects against women are: families are less likely to educate girls than boys, women have to work more hours than men and females receive less health care than males, resulting in low birth weight of babies (Mahendra et. al, 2010). Despite of sufficient production there are other for lack of improvement in Nutritional status in rural areas are: a) Inadequate coverage of children below three years of age who are at greatest risk of malnutrition; b) Irregularity of food deliveries to anganwadis and hence irregular feeding and inadequate rations; c) Poor nutrition education (of mothers and communities) to improve feeding practices at home; d) Inadequate training of workers in nutrition, growth monitoring, and communication; e) Poor supervision; f) Poor co-ordination and linkage with health workers; g) Lack of community ownership and participation (planning commission, GoI).

\section{Suggestions for Improving Food and Nutrition Security in India}

India has taken many efforts to build up a food security system to ensure that the threat of famine like, Investment in agriculture and the green revolution have ensured that the food production has kept pace with the population growth; establishment of adequate buffer stocks has ensured availability of food stuffs within affordable cost even during the times of drought. Moreover, India is currently undergoing demographic, economic, social, educational, and agricultural and health transition. These factors individually and collectively can bring about substantial alteration in health and nutritional status of the population. If through effective planning and inter-sectoral coordination, appropriate synergy is brought about, it will be possible to achieve substantial improvement in nutritional and health status of the population.

Infrastructure and capital flow play critical role in the food production as well growth of economy. Adequate infrastructure facilities such as transport, communications, storage and processing facilities and other factors take part in food security. Policies that encourage holistic approaches including the engagement of the private sector should feature in any national and international approach to address food security. The private sector can invest in clean new technologies and develop innovative market mechanisms to combat climate change on agriculture, livestock and fishery. Reduction in subsidies and increase in investments reform needed in the agriculture sector. Public investment declined from 3.4 per cent of agricultural GDP in the early 1980s to 1.9 per cent in 2001-03. Increase in public and private investment is crucial for enhancing agricultural growth 
and public investment in rural infrastructure, like roads, irrigation, etc is more important than other factors and its investment has increased significantly during this period.

In addition to above, require more focus on productivity attributed factors like soil quality and water management including ground water, and land management should be given the first priority such as investment in irrigation, watershed development, and water conservation practices. All these features take part in the efficient food production and security as well. Furthermore, build up bridge between researchers and farmers on the existing technology and also on extension, because these are crucial for dissemination of information and technology improving agricultural productivity and credit supply to agriculture is increases significantly from last couple of years. But small and marginal farmers still depends on money lenders at village level because of poor and inequality institutional credit to these farming sectors and therefore, essential polices require to modify the existed rules. Other adaptation to change in land use and timing of farming operations, improved crop and livestock management practices including improved input use efficiencies, crop systems diversification, forecasting tools and early warning systems and improve water management. In addition, fragmentation and diversification of land into non-agricultural purposes and non-food crops may also leads to insecurity of food. Need to develop varieties which are resistant to climate change. In other hand, producers share in consumer rupee is very less even consumer pay more price to produce. It's necessary of price stabilization for agricultural produce to safeguard the farmer's interest.

\section{References}

[1]. Angus Deaton and Jean Drèze. 2009. Food and Nutrition in india: Facts and interpretations. February14, 2009. vol xliv No.7EPW Ecoomic \& Political Weekly.

[2]. APFS. 2012. Asia Pacific Food Situation Update. Jan 2012.

[3]. Dev, S.Mahendra. 2003. Right to Food in India. Working Paper no. 50, Centre For Economic and Social Studies, Hyderabad.

[4]. FAO. 2012. FAO statistical Year Book 2012.

[5]. Gol. 2012. Annual report 2011

[6]. GoI. 2012. Economic Survey 2011-12.

[7]. GoI 2011. Ministry of Consumer Affairs, Food and Public Distribution.

[8]. GoI. 2011. Economic Survey 2010-11.

[9]. GoI. 2011. Ministry of Finance, New Delhi, India

[10]. GoI. 2008. 11th Five Year Plan, Planning Commission, Government of India.

[11]. GoI. 2012. Department of Food and Public Distribution System, Govt. of India.

[12]. GoI. 2009. India Country report 2010.

[13]. Ruth Kattumuri. 2011. ASIA RESEARCH CENTRE WORKING PAPER 38.

[14]. S. Mahendra Dev and Alakh N. Sharma. 2010. Food Security in India: Performance, Challenges and Policies, Oxfam India working papers series, September 2010. OIWPS - VII.

[15]. Saxena, N.C. 2008. Hunger, Undernutrition and Food Security in India. New Delhi.

[16]. Sen, Amartya and S. Sengupta. 1983. Malnutrition of Rural Indian Children and the Sex Bias. Economic and Political Weekly, Vol. 19 , No.24

[17]. WHO. 2012. World Hunger report 2012.

[18]. Zeller, M., and M. Sharma. 1998. Rural Finance and Poverty Alleviation. Food Policy Report, IFPRI, Washington D.C.

[19]. http://www.worldhunger.org

[20]. (http://the-diplomat.com).

[21]. http://dbie.rbi.org.in

[22]. http://agricoop.nic.in/

[23]. http://www.indiastat.com

[24]. http://www.fao.org 